\title{
The Global Trends and Regional Differences in Incidence of Hepatitis a From 1990 to 2019 and Implications for Its Prevention
}

\section{Guiying Cao}

Peking University School of Public Health

\section{Wenzhan Jing}

Peking University School of Public Health

Jue Liu

Peking University School of Public Health

Min Liu ( $\square$ liumin@bjmu.edu.cn )

Peking University School of Public Health https://orcid.org/0000-0002-5059-3743

\section{Research Article}

Keywords: Hepatitis A, hepatitis A virus, incident cases, age-standardized incidence rate, trend, Global Burden of Disease, socio-demographic index, prevention, surveillance, vaccination

Posted Date: May 5th, 2021

DOl: https://doi.org/10.21203/rs.3.rs-461125/v1

License: (c) (i) This work is licensed under a Creative Commons Attribution 4.0 International License. Read Full License

Version of Record: A version of this preprint was published at Hepatology International on August 3rd, 2021. See the published version at https://doi.org/10.1007/s12072-021-10232-4. 


\section{Abstract \\ Background \& Purpose}

Despite decades of improved sanitation and hygiene measures and the introduction of hepatitis $\mathrm{A}$ vaccine, hepatitis $A$ has been spread through numerous outbreaks globally. We used data from the Global Burden of Disease (GBD) study to quantify the burden of hepatitis $A$ at the global, regional and national levels.

\section{Methods}

Detailed information on annual incident cases and age-standardized incidence rate (ASR) of hepatitis A between 1990-2019 were derived from the GBD study 2019. Estimated annual percentage change (EAPC) of ASR was calculated to quantify the temporal trends in ASR of hepatitis A.

\section{Results}

Globally, incident cases of hepatitis A increased $13.90 \%$ from 139.54 million in 1990 to 158.94 million in 2019. The ASR of hepatitis A remained stable (EAPC $=0.00,95 \% \mathrm{Cl}:-0.01,0.01)$ worldwide between $1990-$ 2019. However, the ASR of hepatitis A increased in low (EAPC $=0.09,95 \% \mathrm{Cl}: 0.04,0.14)$ and low-middle $(E A P C=0.04,95 \% \mathrm{Cl}: 0.03,0.06)$ socio-demographic index $(S D I)$ regions. For GBD regions, the most significant increases were detected in high-income Asia Pacific (EAPC $=0.53,95 \% \mathrm{Cl}: 0.41,0.66)$, Oceania $(E A P C=0.31,95 \% \mathrm{Cl}: 0.25,0.36)$, and Australasia $(E A P C=0.28,95 \% \mathrm{Cl}: 0.13,0.44)$. Of note, EAPC was positively associated with SDI value in the countries and territories with an SDI value $\geq 0.7(\rho=-0.310, p<$ $0.001)$.

\section{Conclusion}

There is an unfavorable trend that hepatitis $A$ is still pending in hyperendemic regions and is emerging in low endemic regions. These highlight the need of targeted and specific strategies to eliminate hepatitis $A$, such as sanitation measures and a comprehensive plan for surveillance and vaccination against hepatitis A.

\section{Introduction}

Hepatitis A caused by hepatitis A virus (HAV) is the most common form of acute viral hepatitis globally ${ }^{1}$. HAV first identified by Feinstone and colleagues, is a member of the Hepatovirus genus of the family Picornaviridae ${ }^{2,3}$. HAV is transmitted primarily through ingestion of food and water contaminated with the faeces of an infected person or through close physical contact with an infectious person ${ }^{4}$. 
Symptomatic patients of hepatitis A can experience mild to severe illness, including nausea, vomiting, malaise, diarrhea, abdominal discomfort, fever, dark-coloured urine, jaundice, and fulminant hepatitis, which is often fatal ${ }^{5,6}$. However, not everyone with HAV infection will have all of the symptoms. The World Health Organization (WHO) estimates more than 100 million HAV infections, causing approximately 1.5 million clinical cases of hepatitis A each year ${ }^{7}$.

Hepatitis A vaccine is highly immunogenic and well tolerated in preventing hepatitis $A^{8}$. Several randomized controlled trials reported that the efficacy of hepatitis $A$ vaccine used for pre-exposure prophylaxis and post-exposure prophylaxis ranged from $95-100 \%$ among children ${ }^{9-12}$. However, hepatitis A vaccine was used or planned to introduce in routine immunization of children in only 34 countries as of May 2019 worldwide. In addition to the introduction of hepatitis A vaccine, decades of improved sanitation and hygiene measures contribute to combat hepatitis $\mathrm{A}$. The sanitary conditions and hygienic practices were good in high-income countries but still poor in low- and middle-income countries. However, hepatitis A outbreaks frequently occurred in countries regardless of their income in recent years 13-15. In high-income countries, imported frozen produce items and infected travelers from endemic regions are associated with hepatitis $A$ outbreaks ${ }^{15-17}$. Frequent international trades and travels in middle-income countries play important roles in outbreaks of hepatitis $A$ and global transmissions of HAV ${ }^{15}$. For low-income countries, the endemicity levels of hepatitis $A$ is still high due to poor sanitary conditions and hygienic practices ${ }^{15}$. Therefore, the prevention of hepatitis $\mathrm{A}$ is facing more and more complex situations, especially with globalization processes.

Similar with HAV, hepatitis E virus (HEV) is also a leading cause of acute viral hepatitis, and shares a common mode of faecal-oral transmission with HAV. In addition to the faecal-oral route, HEV infection in human often occurs through zoonotic transmission. It has been reported that there are more than 20 million incident HEV infections worldwide, causing approximately 3.3 million symptomatic patients of hepatitis E every year ${ }^{18}$. In our previous study using data from the Global Burden of Disease (GBD) Study 2017, we found that although there was a decreased trend in incidence of hepatitis E from 1990 to 2017 globally, Oceania and Western Europe had an increasing trend in incidence of hepatitis E during this period ${ }^{19}$. Therefore, understanding the endemicity levels of hepatitis $A$ at the global, regional and national levels and targeted strategies for its prevention were essential for achieving the goal of eliminating viral hepatitis by 2030 .

In this current study, we summarized and compared the epidemiology and transmission of HAV and HEV briefly. Then, we extracted detailed data of the incidence of hepatitis A from the GBD Study 2019 to assess the temporal trends in incidence of hepatitis $A$ at global, regional, and national levels from 1990 to 2019. Our study can extend and complement the previous study ${ }^{20}$, while also providing a more comprehensive perspective in the design of targeted strategies in hepatitis A prevention tailored to different countries.

\section{Methods}




\section{Data source}

This study used data of annual incident cases and age-standardized incidence rates (ASRs) of hepatitis A from 1990 to 2019, by sex, age, and location, collected from the Global Health Data Exchange (GHDx) query tool (http://ghdx.healthdata.org/gbd-results-tool) ${ }^{21}$. Data were available from a total of 204 countries and territories, and these were categorized into 5 regions in terms of socio-demographic index (SDI) and 21 GBD regions according to geographical contiguity. The 21 GBD regions, including 5 lowincome regions, 12 middle-income regions, and 4 high-income regions, are listed in Table S1. Specific methods of GBD study 2019 estimation process for the incidence of hepatitis A were described elsewhere ${ }^{22}$. Briefly, age-specific anti-HAV immunoglobulin $\mathrm{G}$ seroprevalence data from population-based studies and surveys were reviewed to estimate the incidence of hepatitis $A$ using the Bayesian meta-regression tool by DisMod-MR 2.1 model ${ }^{22}$.

\section{SDI}

The SDI is a composite indicator of development status strongly correlated with health outcomes ${ }^{21}$. It is the geometric mean of 0 to 1 indices of lag distributed income per capita, average years of schooling for those ages 15 and older, and total fertility rate under the age of 25. A location with an SDI of 0 indicates a theoretical minimum level of development status relevant to health outcomes, while a location with an SDI of 1 indicates a theoretical maximum level ${ }^{21}$. According to SDI values in 2019, the 204 countries and territories were divided into 5 regions, including low, low-middle, middle, high-middle, and high SDI regions. The SDI values of 204 countries and terroirs in 2019 was shown in Table S3.

\section{Statistical analysis}

The percentage changes in hepatitis A incident cases and estimated annual percentage changes (EAPCs) of ASRs were calculated to quantify the trends in incidence of hepatitis A. To compare the incidence rates of hepatitis A across different populations, the ASRs were carried out by applying the age-specific rates for each location, sex and year to a GBD World Standard Population to adjust for potential confounding of age structure ${ }^{23}$. The percentage changes in hepatitis A incident cases from 1990 to 2019 was calculated by the equation:

Percentage changes $=\frac{\text { Incident cases in } 2019-\text { Incident cases in } 1990}{\text { Incident cases in } 1990} \times 100 \%$. summary and widely used measure of the ASR tend over a specified time interval. A regression line was fitted to the natural logarithm of the ASR, i.e. $y=a+\beta x+\varepsilon$, where $y=\ln$ (ASR) and $x=$ calendar year. EAPC was calculated as $100 \times\left(e^{\beta}-1\right)$ and its $95 \%$ confidence interval $(\mathrm{Cl})$ was calculated to reflect the temporal trend in ASR. The trend in ASR was reflected in the EAPC value and its $95 \% \mathrm{Cl}$ : ASR is in an upward trend when the EAPC and the lower boundary of the $95 \% \mathrm{Cl}$ are positive; conversely, ASR is in a downward trend when EAPC and the upper boundary of the $95 \% \mathrm{Cl}$ are negative.

Moreover, the correlations between EAPC and ASR (1990) as well as SDI values (2019) in different countries and territories were evaluated by Pearson correlation analyses to define the potential factors affecting EAPC. The polynomial curves were also modelled. All analyses were conducted with SAS 9.4 
(SAS Institute, Inc., Cary, NC) and Origin 2019b. A two-tailed $p$ value less than 0.05 was considered statistically significant.

\section{Results}

\section{Comparisons of hepatitis A and hepatitis E characteristics}

The characteristics of hepatitis A and hepatitis E were summarized in Table S2, including causative agent, primary route of transmission, reservoir, geographic regions affected, and severity. Hepatitis $A$ and hepatitis $E$ are caused by HAV and HEV, respectively. Both hepatitis $A$ and hepatitis $E$ are generally mild and self-limiting acute illness, but also lead acute liver failure which is rare. The primary route of transmissions of HAV is faecal-oral and that of HEV is zoonotic transmission. Swine and small rodents may serve as an animal reservoir of HEV. Hepatitis A occurs sporadically and in epidemics worldwide, whereas hepatitis E is most common in Central America, Africa, Middle East, India, and Asia.

\section{Global trends in incidence of hepatitis A}

The ASR of hepatitis A varies considerably across the world, with the highest ASR in Comoros $(2,686.34$ per 100,000 in 2019), followed by Djibouti and Tanzania (Fig. 1A). The absolute number of hepatitis A incident cases in India (30.39 million) and China (19.37 million) approximately accounted for one third of hepatitis A incident cases of the global (158.94 million) in 2019 (Table S3).

Globally, the incident cases of hepatitis A increased $13.90 \%$ from 139.54 million in 1990 to 158.94 million in 2019, with the most pronounced increase in Qatar (323.67\%) (Table S3 and Fig. 1B). The overall ASR of hepatitis A remained stable (EAPC $=0.00,95 \% \mathrm{Cl}:-0.01,0.01$ ) from 2,263.97 per 100,000 in 1990 to 2,272.08 per 100,000 in 2019 (Table 1). The ASRs were deemed in an increasing trend in 65 countries or territories, with the largest increase in Thailand (EAPC $=1.35 ; 95 \% \mathrm{Cl}: 0.99,1.71)$, followed by Japan and Germany (Fig. 1C and Table S3). The ASRs remained stable in 35 countries or territories, including the United States of America (USA), Mexico, and Singapore. The remaining 65 countries or territories showed a decreasing trend in ASRs, with the highest decrease in Belarus (EAPC $=-0.76 ; 95 \% \mathrm{Cl}:-0.89,-0.64$ ), followed by Argentina and Romania. 
Table 1

The incident cases and ASRs of hepatitis A in 1990 and 2019 and their temporal trends from 1990 to 2019.

\begin{tabular}{|c|c|c|c|c|c|c|}
\hline \multirow{3}{*}{ Characteristics } & \multicolumn{2}{|l|}{1990} & \multicolumn{2}{|l|}{2019} & \multicolumn{2}{|l|}{ 1990-2019 } \\
\hline & $\begin{array}{l}\text { Incident } \\
\text { cases }\end{array}$ & $\begin{array}{l}\text { ASR per } \\
100,000\end{array}$ & $\begin{array}{l}\text { Incident } \\
\text { cases }\end{array}$ & $\begin{array}{l}\text { ASR per } \\
100,000\end{array}$ & $\begin{array}{l}\text { Percentage } \\
\text { change of }\end{array}$ & EAPC \\
\hline & $\begin{array}{l}\text { No. x } 10^{5} \\
\text { (95\% UI) }\end{array}$ & $\begin{array}{l}\text { No. }(95 \% \\
\text { Ul) }\end{array}$ & $\begin{array}{l}\text { No. } \times 10^{5} \\
(95 \% \text { Ul) }\end{array}$ & No. (95\% UI) & $\begin{array}{l}\text { incident } \\
\text { cases (\%) }\end{array}$ & $\begin{array}{l}(95 \% \\
\mathrm{Cl})\end{array}$ \\
\hline Overall & $\begin{array}{l}1,395.44 \\
(1,303.39, \\
1,484.48)\end{array}$ & $\begin{array}{l}2,263.97 \\
(2,120.55 \\
2,404.67)\end{array}$ & $\begin{array}{l}1,589.44 \\
(1492.31 \\
1,690.85)\end{array}$ & $\begin{array}{l}2,272.08 \\
(2,121.79 \\
2,421.80)\end{array}$ & 13.90 & $\begin{array}{l}0.00 \\
(-0.01 \\
0.01)\end{array}$ \\
\hline \multicolumn{7}{|l|}{ Sex } \\
\hline Male & $\begin{array}{l}712.92 \\
(664.97 \\
759.14)\end{array}$ & $\begin{array}{l}2,255.76 \\
(2111.58 \\
2,398.15)\end{array}$ & $\begin{array}{l}816.21 \\
(764.95, \\
868.13)\end{array}$ & $\begin{array}{l}2,269.94 \\
(2,117.62 \\
2,419.36)\end{array}$ & 14.49 & $\begin{array}{l}0.01 \\
(0.00 \\
0.02)\end{array}$ \\
\hline Female & $\begin{array}{l}682.52 \\
(638.02 \\
725.30)\end{array}$ & $\begin{array}{l}2,272.64 \\
(2,130.30 \\
2,411.24)\end{array}$ & $\begin{array}{l}773.23 \\
(726.79 \\
821.96)\end{array}$ & $\begin{array}{l}2,274.75 \\
(2,125.71 \\
2,421.66)\end{array}$ & 13.29 & $\begin{array}{l}-0.01 \\
(-0.02 \\
0.00)\end{array}$ \\
\hline \multicolumn{7}{|l|}{ SDI } \\
\hline Low & $\begin{array}{l}223.05 \\
(208.56 \\
237.30)\end{array}$ & $\begin{array}{l}2,435.07 \\
(2,274.58 \\
2,597.09)\end{array}$ & $\begin{array}{l}390.12 \\
(364.06 \\
415.51)\end{array}$ & $\begin{array}{l}2,379.07 \\
(2,215.87 \\
2,535.86)\end{array}$ & 74.90 & $\begin{array}{l}0.09 \\
(0.04 \\
0.14)\end{array}$ \\
\hline Low-middle & $\begin{array}{l}377.05 \\
(352.73 \\
402.77)\end{array}$ & $\begin{array}{l}2,326.27 \\
(2,178.11 \\
2,490.21)\end{array}$ & $\begin{array}{l}421.56 \\
(395.19 \\
449.50)\end{array}$ & $\begin{array}{l}2,339.91 \\
(2,185.20 \\
2,499.61)\end{array}$ & 11.80 & $\begin{array}{l}0.04 \\
(0.03 \\
0.06)\end{array}$ \\
\hline Middle & $\begin{array}{l}469.65 \\
(436.39 \\
502.51)\end{array}$ & $\begin{array}{l}2,302.94 \\
(2,143.00 \\
2,461.55)\end{array}$ & $\begin{array}{l}434.57 \\
(404.34 \\
464.46)\end{array}$ & $\begin{array}{l}2,137.82 \\
(1,972.97 \\
2,300.65)\end{array}$ & -7.47 & $\begin{array}{l}-0.10 \\
(-0.15, \\
-0.05)\end{array}$ \\
\hline Middle-high & $\begin{array}{l}235.45 \\
(217.05 \\
253.19)\end{array}$ & $\begin{array}{l}2,132.59 \\
(1,958.05 \\
2,303.65)\end{array}$ & $\begin{array}{l}200.58 \\
(185.08 \\
215.46)\end{array}$ & $\begin{array}{l}1,963.64 \\
(1,777.60 \\
2,144.44)\end{array}$ & -14.81 & $\begin{array}{l}-0.35 \\
(-0.38, \\
-0.31)\end{array}$ \\
\hline High & $\begin{array}{l}89.47 \\
(81.33 \\
97.53)\end{array}$ & $\begin{array}{l}1,248.33 \\
(1,115.17 \\
1,375.23)\end{array}$ & $\begin{array}{l}95.44 \\
(87.17 \\
103.48)\end{array}$ & $\begin{array}{l}1,238.15 \\
(1,104.84 \\
1,372.08)\end{array}$ & 6.67 & $\begin{array}{l}0.02 \\
(-0.03, \\
0.06)\end{array}$ \\
\hline \multicolumn{7}{|l|}{ GBD region } \\
\hline $\begin{array}{l}\text { High-income } \\
\text { Asia Pacific }\end{array}$ & $\begin{array}{l}17.76 \\
(16.09 \\
19.35)\end{array}$ & $\begin{array}{l}1,199.51 \\
(1,067.68, \\
1,331.80)\end{array}$ & $\begin{array}{l}15.63 \\
(14.23, \\
17.09)\end{array}$ & $\begin{array}{l}1,253.14 \\
(1,096.36 \\
1,415.93)\end{array}$ & -12.03 & $\begin{array}{l}0.53 \\
(0.41 \\
0.66)\end{array}$ \\
\hline
\end{tabular}

ASR: age standardized rate; Cl: confidence interval; EAPC: estimated annual percentage change; GBD: Global Burden of Disease; SDI: socio-demographic index; UI: uncertainty interval. 


\begin{tabular}{|c|c|c|c|c|c|c|}
\hline \multirow[t]{3}{*}{ Characteristics } & \multicolumn{2}{|l|}{1990} & \multicolumn{2}{|l|}{2019} & \multicolumn{2}{|l|}{ 1990-2019 } \\
\hline & $\begin{array}{l}\text { Incident } \\
\text { cases }\end{array}$ & $\begin{array}{l}\text { ASR per } \\
100,000\end{array}$ & $\begin{array}{l}\text { Incident } \\
\text { cases }\end{array}$ & $\begin{array}{l}\text { ASR per } \\
100,000\end{array}$ & $\begin{array}{l}\text { Percentage } \\
\text { change of }\end{array}$ & EAPC \\
\hline & $\begin{array}{l}\text { No. } \times 10^{5} \\
(95 \% \text { Ul) }\end{array}$ & $\begin{array}{l}\text { No. }(95 \% \\
\text { UI) }\end{array}$ & $\begin{array}{l}\text { No. } \times 10^{5} \\
(95 \% \text { Ul) }\end{array}$ & No. $(95 \%$ UI) & $\begin{array}{l}\text { incident } \\
\text { cases (\%) }\end{array}$ & $\begin{array}{l}\text { (95\% } \\
\mathrm{Cl})\end{array}$ \\
\hline Central Asia & $\begin{array}{l}22.42 \\
(20.65 \\
24.08)\end{array}$ & $\begin{array}{l}2,547.44 \\
(2,364.30 \\
2,720.15)\end{array}$ & $\begin{array}{l}23.51 \\
(21.70 \\
25.27)\end{array}$ & $\begin{array}{l}2,458.57 \\
(2,270.29 \\
2,642.65)\end{array}$ & 4.87 & $\begin{array}{l}-0.17 \\
(-0.20 \\
-0.15)\end{array}$ \\
\hline East Asia & $\begin{array}{l}287.42 \\
(265.07 \\
309.31)\end{array}$ & $\begin{array}{l}2,288.85 \\
(2,101.12 \\
2,473.66)\end{array}$ & $\begin{array}{l}200.07 \\
(182.44 \\
216.67)\end{array}$ & $\begin{array}{l}1,955.43 \\
(1,752.31 \\
2,152.42)\end{array}$ & -30.39 & $\begin{array}{l}-0.47 \\
(-0.53 \\
-0.42)\end{array}$ \\
\hline South Asia & $\begin{array}{l}360.26 \\
(335.30 \\
388.00)\end{array}$ & $\begin{array}{l}2,262.15 \\
(2,091.44 \\
2,450.07)\end{array}$ & $\begin{array}{l}420.60 \\
(388.3, \\
453.03)\end{array}$ & $\begin{array}{l}2,396.09 \\
(2,221.00 \\
2,575.73)\end{array}$ & 16.75 & $\begin{array}{l}0.19 \\
(0.17 \\
0.21)\end{array}$ \\
\hline $\begin{array}{l}\text { Southeast } \\
\text { Asia }\end{array}$ & $\begin{array}{l}120.29 \\
(109.37 \\
130.96)\end{array}$ & $\begin{array}{l}2,064.02 \\
(1,883.19 \\
2,243.76)\end{array}$ & $\begin{array}{l}121.81 \\
(111.18 \\
132.18)\end{array}$ & $\begin{array}{l}1,980.23 \\
(1,791.74 \\
2,166.75)\end{array}$ & 1.26 & $\begin{array}{l}-0.11 \\
(-0.16 \\
-0.06)\end{array}$ \\
\hline Australasia & $\begin{array}{l}2.02(1.80, \\
2.26)\end{array}$ & $\begin{array}{l}1,081.36 \\
(953.42, \\
1,219.98)\end{array}$ & $\begin{array}{l}2.81(2.49 \\
3.10)\end{array}$ & $\begin{array}{l}1,172.06 \\
(1,014.89 \\
1,319.31)\end{array}$ & 38.64 & $\begin{array}{l}0.28 \\
(0.13 \\
0.44)\end{array}$ \\
\hline Caribbean & $\begin{array}{l}9.78(9.01, \\
10.55)\end{array}$ & $\begin{array}{l}2,416.16 \\
(2,233.05 \\
2,598.65)\end{array}$ & $\begin{array}{l}10.16(9.33 \\
10.94)\end{array}$ & $\begin{array}{l}2,393.01 \\
(2,181.45 \\
2,592.20)\end{array}$ & 3.91 & $\begin{array}{l}-0.06 \\
(-0.08, \\
-0.04)\end{array}$ \\
\hline Central Europe & $\begin{array}{l}19.80 \\
(17.82 \\
21.57)\end{array}$ & $\begin{array}{l}1,888.21 \\
(1,686.40 \\
2,079.67)\end{array}$ & $\begin{array}{l}12.93 \\
(11.75 \\
14.06)\end{array}$ & $\begin{array}{l}1,724.72 \\
(1,534.73 \\
1,911.62)\end{array}$ & -34.70 & $\begin{array}{l}-0.22 \\
(-0.29 \\
-0.15)\end{array}$ \\
\hline $\begin{array}{l}\text { Eastern } \\
\text { Europe }\end{array}$ & $\begin{array}{l}37.79 \\
(34.26 \\
41.00)\end{array}$ & $\begin{array}{l}1,984.65 \\
(1,780.53 \\
2,168.39)\end{array}$ & $\begin{array}{l}29.15 \\
(26.54 \\
31.49)\end{array}$ & $\begin{array}{l}2,012.35 \\
(1,812.10 \\
2,195.27)\end{array}$ & -22.88 & $\begin{array}{l}-0.23 \\
(-0.35 \\
-0.11)\end{array}$ \\
\hline $\begin{array}{l}\text { Western } \\
\text { Europe }\end{array}$ & $\begin{array}{l}35.82 \\
(32.97 \\
38.77)\end{array}$ & $\begin{array}{l}1,090.57 \\
(982.54 \\
1,201.07)\end{array}$ & $\begin{array}{l}37.00 \\
(33.75 \\
40.31)\end{array}$ & $\begin{array}{l}1,083.39 \\
(961.16 \\
1,209.27)\end{array}$ & 3.28 & $\begin{array}{l}0.01 \\
(-0.01 \\
0.04)\end{array}$ \\
\hline $\begin{array}{l}\text { Andean Latin } \\
\text { America }\end{array}$ & $\begin{array}{l}12.61 \\
(11.71, \\
13.54)\end{array}$ & $\begin{array}{l}2,424.94 \\
(2,258.10 \\
2,595.93)\end{array}$ & $\begin{array}{l}15.76 \\
(14.61, \\
16.94)\end{array}$ & $\begin{array}{l}2,448.14 \\
(2,266.14 \\
2,633.15)\end{array}$ & 24.97 & $\begin{array}{l}0.03 \\
(0.01 \\
0.05)\end{array}$ \\
\hline $\begin{array}{l}\text { Central Latin } \\
\text { America }\end{array}$ & $\begin{array}{l}55.94 \\
(52.08, \\
59.83)\end{array}$ & $\begin{array}{l}2,510.55 \\
(2,337.69 \\
2,687.12)\end{array}$ & $\begin{array}{l}57.35 \\
(53.68, \\
61.06)\end{array}$ & $\begin{array}{l}2,476.32 \\
(2,306.59 \\
2,650.84)\end{array}$ & 2.52 & $\begin{array}{l}-0.02 \\
(-0.12 \\
0.07)\end{array}$ \\
\hline $\begin{array}{l}\text { Southern Latin } \\
\text { America }\end{array}$ & $\begin{array}{l}12.52 \\
(11.27 \\
13.61)\end{array}$ & $\begin{array}{l}2,433.41 \\
(2,190.42, \\
2,643.11)\end{array}$ & $\begin{array}{l}11.84 \\
(10.63, \\
12.99)\end{array}$ & $\begin{array}{l}2,084.72 \\
(1,847.54 \\
2,315.62)\end{array}$ & -5.44 & $\begin{array}{l}-0.61 \\
(-0.65, \\
-0.56)\end{array}$ \\
\hline
\end{tabular}




\begin{tabular}{|c|c|c|c|c|c|c|}
\hline \multirow[t]{3}{*}{ Characteristics } & \multicolumn{2}{|l|}{1990} & \multicolumn{2}{|l|}{2019} & \multicolumn{2}{|l|}{ 1990-2019 } \\
\hline & $\begin{array}{l}\text { Incident } \\
\text { cases }\end{array}$ & $\begin{array}{l}\text { ASR per } \\
100,000\end{array}$ & $\begin{array}{l}\text { Incident } \\
\text { cases }\end{array}$ & $\begin{array}{l}\text { ASR per } \\
100,000\end{array}$ & $\begin{array}{l}\text { Percentage } \\
\text { change of }\end{array}$ & EAPC \\
\hline & $\begin{array}{l}\text { No. x } 10^{5} \\
(95 \% \text { Ul) }\end{array}$ & $\begin{array}{l}\text { No. }(95 \% \\
\text { Ul) }\end{array}$ & $\begin{array}{l}\text { No. x } 10^{5} \\
\text { (95\% UI) }\end{array}$ & No. (95\% UI) & $\begin{array}{l}\text { incident } \\
\text { cases }(\%)\end{array}$ & $\begin{array}{l}\text { No. } \\
(95 \% \\
\text { Cl) }\end{array}$ \\
\hline $\begin{array}{l}\text { Tropical Latin } \\
\text { America }\end{array}$ & $\begin{array}{l}39.36 \\
(36.37 \\
42.56)\end{array}$ & $\begin{array}{l}2,177.36 \\
(2,006.98 \\
2,354.96)\end{array}$ & $\begin{array}{l}38.30 \\
(34.98 \\
41.31)\end{array}$ & $\begin{array}{l}2,004.49 \\
(1,806.14 \\
2,194.00)\end{array}$ & -2.68 & $\begin{array}{l}-0.63 \\
(-0.75 \\
-0.51)\end{array}$ \\
\hline $\begin{array}{l}\text { North Africa } \\
\text { and Middle } \\
\text { East }\end{array}$ & $\begin{array}{l}117.34 \\
(108.34 \\
126.35)\end{array}$ & $\begin{array}{l}2,346.16 \\
(2,175.08 \\
2,520.42)\end{array}$ & $\begin{array}{l}145.52 \\
(134.95 \\
155.99)\end{array}$ & $\begin{array}{l}2,341.72 \\
(2,165.93 \\
2,517.09)\end{array}$ & 24.02 & $\begin{array}{l}-0.06 \\
(-0.09 \\
-0.04)\end{array}$ \\
\hline $\begin{array}{l}\text { High-income } \\
\text { North America }\end{array}$ & $\begin{array}{l}28.91 \\
(25.85 \\
31.96)\end{array}$ & $\begin{array}{l}1,134.75 \\
(1,003.57 \\
1,265.13)\end{array}$ & $\begin{array}{l}34.87 \\
(31.43 \\
38.22)\end{array}$ & $\begin{array}{l}1,180.02 \\
(1,042.22 \\
1,317.73)\end{array}$ & 20.63 & $\begin{array}{l}-0.02 \\
(-0.13 \\
0.09)\end{array}$ \\
\hline Oceania & $\begin{array}{l}1.88(1.69 \\
2.08)\end{array}$ & $\begin{array}{l}2,124.87 \\
(1,928.54 \\
2,323.02)\end{array}$ & $\begin{array}{l}3.91 \text { (3.51, } \\
4.29)\end{array}$ & $\begin{array}{l}2,312.83 \\
(2,096.23 \\
2,514.24)\end{array}$ & 107.85 & $\begin{array}{l}0.31 \\
(0.25 \\
0.36)\end{array}$ \\
\hline $\begin{array}{l}\text { Central Sub- } \\
\text { Saharan } \\
\text { Africa }\end{array}$ & $\begin{array}{l}24.68 \\
(22.71 \\
26.55)\end{array}$ & $\begin{array}{l}2,587.18 \\
(2,417.58 \\
2,752.66)\end{array}$ & $\begin{array}{l}49.09 \\
(45.35 \\
52.63)\end{array}$ & $\begin{array}{l}2,543.07 \\
(2,368.10 \\
2,713.33)\end{array}$ & 98.94 & $\begin{array}{l}-0.04 \\
(-0.05 \\
-0.03)\end{array}$ \\
\hline $\begin{array}{l}\text { Eastern Sub- } \\
\text { Saharan } \\
\text { Africa }\end{array}$ & $\begin{array}{l}87.90 \\
(82.02 \\
93.58)\end{array}$ & $\begin{array}{l}2,514.24 \\
(2,338.12 \\
2,700.57)\end{array}$ & $\begin{array}{l}163.24 \\
(151.74, \\
173.83)\end{array}$ & $\begin{array}{l}2,625.34 \\
(2,425.49 \\
2,802.26)\end{array}$ & 85.71 & $\begin{array}{l}0.10 \\
(0.08 \\
0.12)\end{array}$ \\
\hline $\begin{array}{l}\text { Southern Sub- } \\
\text { Saharan } \\
\text { Africa }\end{array}$ & $\begin{array}{l}17.91 \\
(16.61 \\
19.16)\end{array}$ & $\begin{array}{l}2,511.09 \\
(2,320.54 \\
2,701.95)\end{array}$ & $\begin{array}{l}20.74 \\
(19.12 \\
22.26)\end{array}$ & $\begin{array}{l}2,526.16 \\
(2,333.32 \\
2,706.97)\end{array}$ & 15.85 & $\begin{array}{l}0.01 \\
(0.00 \\
0.02)\end{array}$ \\
\hline $\begin{array}{l}\text { Western Sub- } \\
\text { Saharan } \\
\text { Africa }\end{array}$ & $\begin{array}{l}83.03 \\
(77.09 \\
88.91)\end{array}$ & $\begin{array}{l}2,546.44 \\
(2,371.18 \\
2,713.40)\end{array}$ & $\begin{array}{l}175.15 \\
(162.47 \\
187.36)\end{array}$ & $\begin{array}{l}2,552.05 \\
(2,379.50 \\
2,723.25)\end{array}$ & 110.95 & $\begin{array}{l}0.00 \\
(-0.01 \\
0.01)\end{array}$ \\
\hline
\end{tabular}

\section{Trends in incidence of hepatitis A across 5 SDI regions}

For the $5 \mathrm{SDI}$ regions, the number of hepatitis A incident cases increased in low (74.90\%), low-middle (11.80\%), and high (6.67\%) SDI regions but decreased in middle (7.74\%) and middle-high (14.81\%) SDI regions (Table 1). The ASR increased in low $(E A P C=0.09 ; 95 \% \mathrm{Cl}: 0.04,0.14)$ and low-middle $(E A P C=$ 0.04; 95\% Cl: 0.03, 0.06) SDI regions but decreased in middle (EAPC $=-0.10 ; 95 \% \mathrm{Cl}:-0.15,-0.05)$ and middle-high (EAPC $=-0.35 ; 95 \% \mathrm{Cl}:-0.38,-0.31)$ SDI region. The ASR remained stable in high SDI regions $(E A P C=0.02 ; 95 \% \mathrm{Cl}:-0.03,0.06)$.

Figure 3 shows the number of incidents cases of hepatitis A by age at 5 SDI regions from 1990 to 2019. In low SDI regions, the growing number of incident cases of hepatitis A was due to the gradual increase in 
the number of cases in all age groups, especially in children aged under 5 years (Fig. 3A). The increased incidents cases of children aged under 5 years accounted for $50.16 \%$ of the total increased incident cases from 1990 to 2019. However, the number of incident cases was deceasing only in children aged under 5 years but increasing in other age groups in low-middle SDI regions. In middle and above SDI regions (including middle, middle-high, and high SDI regions), the number of incident cases was decreasing in children aged less than 15 years but increasing in population aged 15 years plus.

\section{Trends in incidence of hepatitis A across 21 GBD regions}

For the $21 \mathrm{GBD}$ regions, low-income regions suffered the severest threat of hepatitis $\mathrm{A}$, with the highest ASR of 2,625.34 per 100,000 in Eastern Sub-Saharan Africa, followed by Western Sub-Saharan Africa (2,625.34 per 100,000 in 2019) and Central Sub-Saharan Africa (2,543.07 per 100,000 in 2019) in 2019 (Table 1). The trends in ASRs of hepatitis A were heterogeneous across the 21 GBD regions, with the highest increasing trend in high-income Asia Pacific (EAPC $=0.53 ; 95 \% \mathrm{Cl}: 0.41,0.66)$, Oceania (EAPC = $0.31 ; 95 \% \mathrm{Cl}: 0.25,0.36)$, and Australasia (EAPC $=0.28 ; 95 \% \mathrm{Cl}: 0.13,0.44)$; and stable in Western Europe, Central Latin America, North Africa and Middle East and Western Sub-Saharan Africa. Nearly all middleincome regions a decreased trend in ASRs of hepatitis A.

Figure 4 shows the proportions of incidents cases of hepatitis A by age at 21 GBD regions in 1990 and 2019. The children aged under 5 years accounted for approximately $50 \%$ incident cases globally, and even about 70\% in some low-income regions, including Eastern Sub-Saharan Africa and Southern SubSaharan Africa. All high-income regions, including high-income Asia Pacific, Australasia, Western Europe and high-income North America, had a much lower proportions of incident cases among children aged under 5 which was less than $20 \%$. However, adults aged $15-39$ years had the highest proportions of incident cases in these high-income regions. In addition, the proportions of incident cases were high in older adults aged 60 years and older in these regions, even 10.18\% in Western European.

\section{Factors associated with EAPC}

A significant negative correlation was observed between EAPC and ASR in $1990(\rho=-0.176, p=0.012)$ (Fig. 5A). Surprisingly, a significant positive correlation was detected between EAPC and SDI ( $\rho=0.371, p$ $<0.001$ ) for the countries and territories with an SDI value $\geq 0.7$, while a significant negative correlation was observed in the countries and territories with an SDI value $<0.7(\rho=-0.310, p<0.001)$ (Fig. 5B). For an SDI value $\geq 0.7$, countries or territories with higher SDI have experienced an increased trend in ASR from 1990 to 2019.

\section{Discussion}

This study assessed the global landscape, long-term trends, and regional differences in incidence of hepatitis A using a post-hoc analysis of data from the GBD study 2019. Globally, the ASR of hepatitis A remained stable from 1990 to 2019, while the number of incident cases has increased by $13.90 \%$ in this period. Of note, hepatitis $A$ is not only still pending in hyperendemic regions but also emerging in low endemic regions. For example, low-income regions suffered the severest threat of hepatitis $A$, with the 
highest ASR of hepatitis A in Eastern Sub-Saharan Africa, Western Sub-Saharan Africa, and Central SubSaharan Africa in 2019. In low and low-middle SDI regions, not only the ASR of hepatitis A has increased, but the number of incident cases has also remarkably increased from 1990 to 2019. In addition, highincome Asia Pacific, Oceania, and Australasia had the highest increasing trend in ASR of hepatitis A from 1990 to 2019. Therefore, facing with the unfavorable trend in ASR of hepatitis A, novel challenges were posed for controlling or eliminating this disease.

This study found that the incident cases of hepatitis A increased globally between 1990 and 2019. The increased incident cases were primarily driven by population growth across the globe, specifically in lowincome and middle-income countries. China and India with the world's largest population, over 2.8 billion, accounting for nearly $40 \%$ of the earth's inhabitants, had approximately one third of hepatitis A incident cases of the global in $2019{ }^{24}$. Moreover, immigrant growth may also play an important role in driving the increase of incident cases of hepatitis A. For example, we found the largest increase of incident cases of hepatitis A in Qatar where large numbers of immigrant workers often from low-income countries have been drawn in the last two decades ${ }^{25}$. In the growing population of immigrant families, pediatric travelers could be silent reservoirs of hepatitis $A$ after return from the visiting of friends and relatives travel ${ }^{26}$. Finally, the number of hepatitis $A$ cases could increase with the globalization processes and increased high-risk populations of hepatitis $A^{15,27}$.

Consistent with previous studies ${ }^{20,28}$, this study found the incidence of hepatitis A being closely related to socioeconomic development. We found that hepatitis A tended to be more prevalent in low-income regions, including Sub-Saharan Africa and South Asia, where HAV is highly endemic and most persons become infected in early childhood ${ }^{20}$. Poor sanitary and hygienic conditions contributed to the propagation of HAV in low-income regions, including household crowding, poor levels of sanitation and inadequate water supplies ${ }^{20,29}$. In addition, we found a decreased trend in incidence of hepatitis $A$ in most middle-income regions, but an increased trend in Andean Latin America and Oceania. In middleincome regions, despite sanitary and hygienic conditions varying, nearly all populations have access to clean water and some children during their early childhood can avoid HAV infection, especially in urban areas ${ }^{15,20}$. In this study, we found a lower proportions of incident cases in children aged under 5 years in middle-income regions than low-income regions. Finally, we found that the trends in incidence of hepatitis A increased in two high-income regions, including high-income Asia Pacific and Australasia. Good sanitation and hygienic conditions are available and infection rates of hepatitis $A$ in children are generally low in most high-income countries ${ }^{20,29}$. However, most adults are still susceptible to HAV infection and foodborne outbreaks of hepatitis $A$ are becoming more frequent in high-income regions ${ }^{15}$. The peak rates of HAV infection tend to occur in adolescents and young adults. In addition, the burden of hepatitis A still significantly attribute to large community-wide outbreaks with person-to-person transmission. Finally, HAV infection predominates among persons at high risk in these high-income regions, such as travelers to countries with high endemicity levels of hepatitis $A$, men who have sex with men (MSM), persons who inject drugs (PWIDs), and homeless persons ${ }^{20,27,29,30}$. 
We found that the trends in incidence of hepatitis A decreased in most countries and territories, such as Belarus, China, and Brazil. In these countries, rising socioeconomic levels and increased access to good sanitation and hygiene facilities and clean drinking water contributed to the decreased incidence of hepatitis $A^{15,28,31}$. In addition, the availability of a hepatitis $A$ vaccine that was developed in the 1990 s also played an important role in reducing this disease incidence ${ }^{8,29,32}$. For example, a shellfishassociated hepatitis A outbreak caused 300,000 cases in Shanghai, China, in two months of the first quarter of $1988^{33}$. With the very rapid socioeconomic development, improved sanitary and hygienic conditions, and the introduction of hepatitis A vaccine in China, the incidence rate of hepatitis A dropped dramatically in the following couple of decades ${ }^{34-36}$. Despite the above effective ways combating hepatitis A being available for several decades, the incidence of hepatitis A still increased in high endemic countries and even some low endemic countries, such as Japan, Germany, Canada, and Italy. In countries with high endemicity levels of hepatitis A, HAV is wide spread due to poor sanitary conditions and hygienic practices, leading an increased trend in incidence of hepatitis $A^{15}$. In the countries where the risk of HAV infection from food or water is low, there were hepatitis $A$ outbreaks among population at high risk of hepatitis $A^{14,37-42}$. For example, hepatitis $A$ outbreaks were particularly driven by transmission between non-immune MSM engaging in high-risk sexual behavior, which has been reported in European and United States populations ${ }^{14,38-41}$. In addition, hepatitis A outbreaks often occurred among PWIDs, and homelessness in United States ${ }^{14,42}$. Finally, globalization have driven increased international trade, migration and travel which are expected to increase foodborne outbreaks of hepatitis A in high-income countries ${ }^{6,15}$. In the last decades, imported frozen berries have caused numerous foodborne outbreaks of hepatitis A in Australia and Europe ${ }^{16,43,44}$. Hepatitis A outbreaks usually occurred when residents in low endemic countries migrated and traveled to areas with high endemicity levels of HAV ${ }^{15}$. Evidence has reported that the hepatitis A outbreaks in Hispanic children in urban areas of the United States-Mexico border were significantly associated with cross-border travel from the United States to Mexico and foodborne exposures during the travel ${ }^{45}$. Therefore, facing with the complex situation of hepatitis $A$, more efforts should be done to eliminate hepatitis A infection globally.

In this study, a faster decreasing temporal trend in ASR of hepatitis A between 1990 and 2019 was observed in the country with a higher baseline ASR in 1990. It was probably because the country with higher baseline ASR was easier to reduce the massive hepatitis A outbreaks by the development of countries' economies and public-health infrastructure, as well as the introduce of hepatitis A vaccine ${ }^{15}$. Furthermore, we found that in the countries or territories with an SDI value $\geq 0.7$, those with higher SDI have experienced an increased trend in ASR of hepatitis A from 1990 to 2019. The possible explanations might be that the increasing age at midpoint of population immunity could increase the hepatitis $A$ cases in high-risk populations which is more likely in high SDI countries, leading an increased ASR in these countries ${ }^{6}$.

The risk of hepatitis A outbreaks can persist for extended time periods in unvaccinated individuals ${ }^{15}$. Thus, prevention measures that can reduce the risk for transmission of HAV should be emphasized. 
Sanitation measures play an important role in HAV infection prevention, including but not limited to careful attention to hygiene, particularly in the food service industry ${ }^{26}$. Heating foods to $185^{\circ} \mathrm{F}\left(85^{\circ} \mathrm{C}\right)$ for one minute, use of a 1:100 solution of household bleach, handwashing, and avoiding contact with uncooked foods, are all techniques that may reasonably decrease the likelihood of hepatitis A transmission ${ }^{46}$. In addition, prophylaxis of vulnerable populations and children through active or passive immunization is the most important prevention practice ${ }^{8,47,48}$. WHO recommends that hepatitis $\mathrm{A}$ vaccine be integrated into the national immunization schedule for children aged 1 year and older in countries where clinical hepatitis $A$ is an important health problem and immunization is likely to be a cost-effective public health tool to control this disease ${ }^{49}$. The recommendations for vaccination varied by the countries' endemicity of hepatitis A. In high endemic countries, large-scale immunization efforts against hepatitis $A$ should not be undertaken due to near universal immunity from asymptomatic childhood infections. Nationwide vaccination might be considered in intermediate endemic countries where the transmission of HAV occurs primarily from person to person in the general community. In low endemic countries, vaccination is considered for high-risk groups, such as MSM, PWIDs, homelessness and persons travelling to high-risk areas. The comprehensive plan for the prevention and control of viral hepatitis also should take surveillance and vaccination against hepatitis A into it's a part.

Based on this current study and our previous study ${ }^{19}$, we found that the trends in incidence of hepatitis A and hepatitis $\mathrm{E}$, the two common forms of acute viral hepatitis, varied at global and regional levels. The geographic variations in endemicity of HAV and HEV can be related to economic development and sanitation practices ${ }^{15,50}$. However, both hepatitis $A$ and hepatitis $E$ are still pending in hyperendemic regions and are emerging in low endemic regions. The vaccine of hepatitis $A$ has been available and used in many countries; however, a vaccine to prevent HEV infection has been developed and is licensed in China, but is not yet available elsewhere ${ }^{51}$. Considering the similar epidemiology and transmission of HAV to that of HEV, the target and specific strategies for ensuring good hygiene and sanitations and food safety that can eliminate hepatitis A are also beneficial for eliminating hepatitis E. Moreover, avoiding close contact with animals also important preventive measure for HEV due to that a wide range of domestic or wild animals have been recognized as reservoirs for the zoonotic strains ${ }^{52}$.

The GBD study provides a better understanding of the trend in incidence of hepatitis A over the last couple decades globally. Some limitations in this study should also be acknowledged. First, the accuracy and robustness of GBD estimates largely depend on the quality and quantity of data used in the modeling ${ }^{19,23}$. Second, due to the GBD study taking the country as its basic unit, the incidence of hepatitis A might be a margin of bias in countries in lack of national systematic surveillance and population-based studies of hepatitis A. Third, although the standardization makes the incidence rates of hepatitis A comparable at the global, regional and national levels, the ASR of hepatitis A only reflects the burden of hepatitis A for one region or country under the age structure of a GBD World Standard Population.

\section{Conclusion}


In summary, there is an unfavorable trend in ASR of hepatitis A that it is still pending in hyperendemic regions and is emerging in low endemic regions globally. Due to the rapid globalization processes and increased high-risk populations of hepatitis $A$, the number of hepatitis A cases is probably in an increasing trend, posing novel challenges for eliminating this disease, especially in high-income regions. Thus, more targeted and specific strategies were need to eliminate hepatitis A, such as sanitation measures and a comprehensive plan for surveillance and vaccination against hepatitis A. Future studies focusing on targeted prevention and control strategies for hepatitis A were warranted.

\section{Declarations}

\section{Data Availability}

All data were obtained from the Global Health Data Exchange (GHDx) query tool (http://ghdx.healthdata.org/gbd-results-tool).

\section{Animal Research}

Not applicable.

\section{Consent to Participate}

Not applicable.

\section{Consent to Publish}

Not applicable.

\section{Plant Reproducibility}

Not applicable.

\section{Clinical Trials Registration}

Not applicable.

\section{Author Contribution}

GC searched the literature, designed the study, analyzed the data, interpreted the results, and drafted the manuscript; WJ designed the study, interpreted the results, and drafted the manuscript. JL and ML conceived the study, designed the study, supervised the study, interpreted the results, and revised the manuscript. All authors approved the final version of the manuscript.

\section{Conflict of Interest}

The authors declare that they have no conflict of interest. 


\section{Funding}

This work was supported by the National Natural Science Foundation of China (grant number: 71934002, 71874003) and National Key Research and Development Program of China (grant number: 2020YFC0846300). The funders had no role in study design, data collection and analysis, decision to publish, or preparation of the paper. No payment was received by any of the co-authors for the preparation of this article.

\section{Gels and Blots}

Not applicable.

\section{References}

1. Linder KA, Malani PN. Hepatitis A. JAMA. 2017;318(23):2393. doi: 10.1001/jama.2017.17244.

2. Feinstone SM, Kapikian AZ, Purceli RH. Hepatitis A: detection by immune electron microscopy of a viruslike antigen associated with acute illness. Science. 1973;182(4116):1026-1028. doi: 10.1126/science.182.4116.1026.

3. Koff RS. Hepatitis A. Lancet. 1998;351(9116):1643-1649. doi: 10.1016/s0140-6736(98)01304-x.

4. Wenzel JJ, Allerberger F. Hepatitis A as a foodborne infection. Lancet Infect Dis. 2014;14(10):907908. doi: 10.1016/s1473-3099(14)70897-7.

5. Shin EC, Jeong SH. Natural History, Clinical Manifestations, and Pathogenesis of Hepatitis A. Cold Spring Harb Perspect Med. 2018;8(9). doi: 10.1101/cshperspect.a031708.

6. Lemon SM, Ott JJ, Van Damme P, Shouval D. Type A viral hepatitis: A summary and update on the molecular virology, epidemiology, pathogenesis and prevention. J Hepatol. 2017. doi: 10.1016/j.jhep.2017.08.034.

7. WHO. WHO Position paper on hepatitis A vaccines. Weekly epidemiological record. 2012;87(2829):261-276. PMID: 10769944.

8. Zhang L. Hepatitis A vaccination. Hum Vaccin Immunother. 2020;16(7):1565-1573. doi: $10.1080 / 21645515.2020 .1769389$.

9. Lifely MR, Rogers MV, Esdaile J, Payne M, Tite JP. Murine cross-reactive T-cell epitopes of Neisseria meningitidis outer membrane proteins. Vaccine. 1992;10(3):159-163. doi: 10.1016/0264410x(92)90005-5.

10. Werzberger A, Mensch B, Kuter B, et al. A controlled trial of a formalin-inactivated hepatitis A vaccine in healthy children. N Engl J Med. 1992;327(7):453-457. doi: 10.1056/nejm199208133270702.

11. Xu Z, Wang X, Li R, et al. [Immunogenicity and efficacy of two live attenuated hepatitis A vaccines (H(2) strains and LA-1 strains)]. Zhonghua Yi Xue Za Zhi. 2002;82(10):678-681.

12. Mao JS, Chai SA, Xie RY, et al. Further evaluation of the safety and protective efficacy of live attenuated hepatitis A vaccine (H2-strain) in humans. Vaccine. 1997;15(9):944-947. doi: 
10.1016/s0264-410x(96)00304-0.

13. Hu X, Collier MG, Xu F. Hepatitis A Outbreaks in Developed Countries: Detection, Control, and Prevention. Foodborne Pathog Dis. 2020;17(3):166-171. doi: 10.1089/fpd.2019.2648.

14. Foster MA, Hofmeister MG, Kupronis BA, et al. Increase in hepatitis A virus infections - United States, 2013-2018. MMWR Morb Mortal Wkly Rep. 2019;68(18):413-415. doi: 10.15585/mmwr.mm6818a2.

15. Jacobsen $\mathrm{KH}$. Globalization and the changing epidemiology of hepatitis A virus. Cold Spring Harb Perspect Med. 2018;8(10). doi: 10.1101/cshperspect.a031716.

16. Bozkurt H, Phan-Thien KY, van Ogtrop F, Bell T, McConchie R. Outbreaks, occurrence, and control of norovirus and hepatitis a virus contamination in berries: A review. Crit Rev Food Sci Nutr. 2021;61(1):116-138. doi: 10.1080/10408398.2020.1719383.

17. Greig JD, Ravel A. Analysis of foodborne outbreak data reported internationally for source attribution. Int J Food Microbiol. 2009;130(2):77-87. doi: 10.1016/j.ijfoodmicro.2008.12.031.

18. Rein DB, Stevens GA, Theaker J, Wittenborn JS, Wiersma ST. The global burden of hepatitis E virus genotypes 1 and 2 in 2005. Hepatology. 2012;55(4):988-997. doi: 10.1002/hep.25505.

19. Jing W, Liu J, Liu M. The global trends and regional differences in incidence of HEV infection from 1990 to 2017 and implications for HEV prevention. Liver Int. 2021;41(1):58-69. doi: 10.1111/liv.14686.

20. Jacobsen KH, Wiersma ST. Hepatitis A virus seroprevalence by age and world region, 1990 and 2005. Vaccine. 2010;28(41):6653-6657. doi: 10.1016/j.vaccine.2010.08.037

21. Global Burden of Disease Collaborative Network. Global Burden of Disease Study 2019 (GBD 2019) Results. Seattle, United States: Institute for Health Metrics and Evaluation (IHME), 2020. Available from http://ghdx.healthdata.org/gbd-results-tool.

22. Global burden of 369 diseases and injuries in 204 countries and territories, 1990-2019: a systematic analysis for the Global Burden of Disease Study 2019. Lancet. 2020;396(10258):1204-1222. doi: 10.1016/s0140-6736(20)30925-9.

23. Liu Z, Jiang $Y$, Yuan $\mathrm{H}$, et al. The trends in incidence of primary liver cancer caused by specific etiologies: Results from the Global Burden of Disease Study 2016 and implications for liver cancer prevention. J Hepatol. 2019;70(4):674-683. doi: 10.1016/j.jhep.2018.12.001.

24. United Nations, Department of Economic and Social Affairs, Population Division (2019). World Population Prospects 2019, Online Edition. Rev. 1. https://population.un.org/wpp/.

25. Abu-Madi MA, Behnke JM, Ismail A, Al-Olaqi N, Al-Zaher K, El-Ibrahim R. Comparison of intestinal parasitic infection in newly arrived and resident workers in Qatar. Parasit Vectors. 2011;4:211. doi: 10.1186/1756-3305-4-211.

26. Trujillo-Ochoa JL, Viera-Segura O, Fierro NA. Challenges in Management of Hepatitis A Virus Epidemiological Transition in Mexico. Ann Hepatol. 2019;18(1):14-22. doi: 10.5604/01.3001.0012.7857. 
27. Franco E, Giambi C, lalacci R, Coppola RC, Zanetti AR. Risk groups for hepatitis A virus infection. Vaccine. 2003;21(19-20):2224-2233. doi: 10.1016/s0264-410x(03)00137-3.

28. Jacobsen KH, Koopman JS. The effects of socioeconomic development on worldwide hepatitis $A$ virus seroprevalence patterns. Int J Epidemiol. 2005;34(3):600-609. doi: 10.1093/ije/dyi062.

29. Wasley A, Fiore A, Bell BP. Hepatitis A in the era of vaccination. Epidemiol Rev. 2006;28:101-111. doi: 10.1093/epirev/mxj012.

30. Sane J, MacDonald E, Vold L, Gossner C, Severi E. Multistate foodborne hepatitis A outbreak among European tourists returning from Egypt-need for reinforced vaccination recommendations, November 2012 to April 2013. Euro Surveill. 2015;20(4). doi: 10.2807/1560-7917.es2015.20.4.21018.

31. Franco E, Meleleo C, Serino L, Sorbara D, Zaratti L. Hepatitis A: Epidemiology and prevention in developing countries. World J Hepatol. 2012;4(3):68-73. doi: 10.4254/wjh.v4.i3.68.

32. WHO position paper on hepatitis A vaccines - June 2012. Wkly Epidemiol Rec. 2012;87(28/29):261276. PMID: 22905367.

33. Halliday ML, Kang LY, Zhou TK, et al. An epidemic of hepatitis A attributable to the ingestion of raw clams in Shanghai, China. J Infect Dis. 1991;164(5):852-859. doi: 10.1093/infdis/164.5.852.

34. Sun XJ, Zhang GM, Zhou RJ, et al. Changes in the epidemiology of hepatitis A in three socioeconomic regions of China, 1990-2017. Infect Dis Poverty. 2019;8(1):80. doi: 10.1186/s40249-0190591-z.

35. Wang F, Sun X, Wang F, et al. Changing Epidemiology of Hepatitis A in China: Evidence From Three National Serological Surveys and the National Notifiable Disease Reporting System. Hepatology. 2020. doi: 10.1002/hep.31429.

36. Cui F, Liang X, Wang F, Zheng H, Hutin YJ, Yang W. Development, production, and postmarketing surveillance of hepatitis A vaccines in China. J Epidemiol. 2014;24(3):169-177. doi: 10.2188/jea.je20130022.

37. Sachdeva H, Benusic M, Ota S, et al. Community outbreak of hepatitis A disproportionately affecting men who have sex with men in Toronto, Canada, January 2017-November 2018. Can Commun Dis Rep. 2019;45(10):262-268. doi: 10.14745/ccdr.v45i10a03.

38. Ndumbi P, Freidl GS, Williams CJ, et al. Hepatitis A outbreak disproportionately affecting men who have sex with men (MSM) in the European Union and European Economic Area, June 2016 to May 2017. Euro Surveill. 2018;23(33). doi: 10.2807/1560-7917.es.2018.23.33.1700641.

39. Bordi L, Rozera G, Scognamiglio P, et al. Monophyletic outbreak of Hepatitis A involving HIV-infected men who have sex with men, Rome, Italy 2008-2009. J Clin Virol. 2012;54(1):26-29. doi: 10.1016/j.jcv.2012.01.009.

40. Mazick A, Howitz M, Rex S, et al. Hepatitis A outbreak among MSM linked to casual sex and gay saunas in Copenhagen, Denmark. Euro Surveill. 2005;10(5):111-114. PMID: 16077208.

41. Taffon S, Bidini G, Vichi F, et al. A unique HAV strain circulated in patients with acute HAV infection with different risk exposures in Tuscany, Italy. J Clin Virol. 2011;50(2):142-147. doi: 10.1016/j.jcv.2010.10.011. 
42. Nelson R. Hepatitis A outbreak in the USA. Lancet Infect Dis. 2018;18(1):33-34. doi: 10.1016/s14733099(17)30718-1.

43. Tavoschi L, Severi E, Niskanen T, et al. Food-borne diseases associated with frozen berries consumption: a historical perspective, European Union, 1983 to 2013. Euro Surveill. 2015;20(29):21193. doi: 10.2807/1560-7917.es2015.20.29.21193.

44. Franklin N, Camphor H, Wright R, Stafford R, Glasgow K, Sheppeard V. Outbreak of hepatitis A genotype IB in Australia associated with imported frozen pomegranate arils. Epidemiol Infect. 2019;147:e74. doi: 10.1017/s0950268818003515.

45. Weinberg M, Hopkins J, Farrington L, Gresham L, Ginsberg M, Bell BP. Hepatitis A in Hispanic children who live along the United States-Mexico border: the role of international travel and food-borne exposures. Pediatrics. 2004;114(1):e68-73. doi: 10.1542/peds.114.1.e68.

46. Matheny SC, Kingery JE. Hepatitis A. Am Fam Physician. 2012;86(11):1027-1034; quiz 1010-1022. PMID: 23198670.

47. Hilleman MR. Hepatitis and hepatitis A vaccine: a glimpse of history. J Hepatol. 1993;18 Suppl 2:S510. doi: 10.1016/s0168-8278(05)80370-8.

48. Fisenka EG, Germanovich FA, Glinskaya IN, Lyabis OI, Rasuli AM. Effectiveness of universal hepatitis A immunization of children in Minsk City, Belarus: four-year follow-up. J Viral Hepat. 2008;15 Suppl 2:57-61. doi: 10.1111/j.1365-2893.2008.01031.x.

49. WHO. Hepatitis A: Vaccine Preventable Diseases Surveillance Standards. 2018. Available from: http://apps.who.int/iris/bitstream/handle/10665/204501/9789241549547_eng.pdf?sequence=1.

50. Nelson KE, Labrique AB, Kmush BL. Epidemiology of Genotype 1 and 2 Hepatitis E Virus Infections. Cold Spring Harb Perspect Med. 2019;9(6). doi: 10.1101/cshperspect.a031732.

51. World Health Organization Hepatitis E vaccine: WHO position paper Wkly Epidemiol Rec, 90 (2015), pp 185-200. PMID: 25935931.

52. Kamar N, Izopet J, Pavio N, et al. Hepatitis E virus infection. Nat Rev Dis Primers. 2017;3:17086. doi: 10.1038/nrdp.2017.86.

\section{Figures}



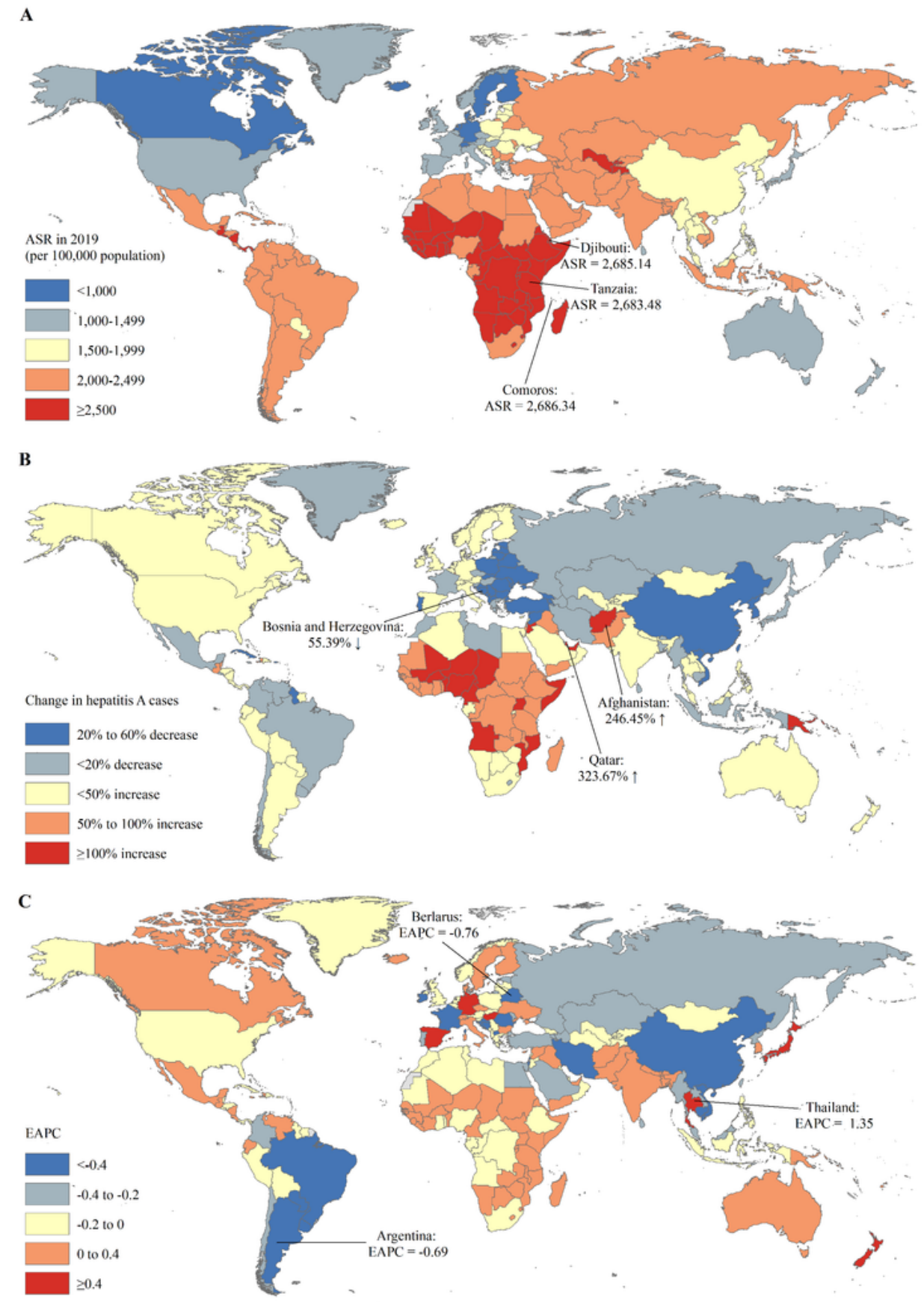

\section{Figure 1}

The global trends in incidence of hepatitis A in 204 countries and territories. (A) The ASRs of hepatitis A in 2019; (B) The relative change in incident cases of hepatitis A between 1990 and 2019; (C) The EAPCs of hepatitis A ASRs from 1990 to 2019. ASR, age-standardized incidence rate; EAPC, estimated annual percentage change. Note: The designations employed and the presentation of the material on this map do not imply the expression of any opinion whatsoever on the part of Research Square concerning the 
legal status of any country, territory, city or area or of its authorities, or concerning the delimitation of its frontiers or boundaries. This map has been provided by the authors.

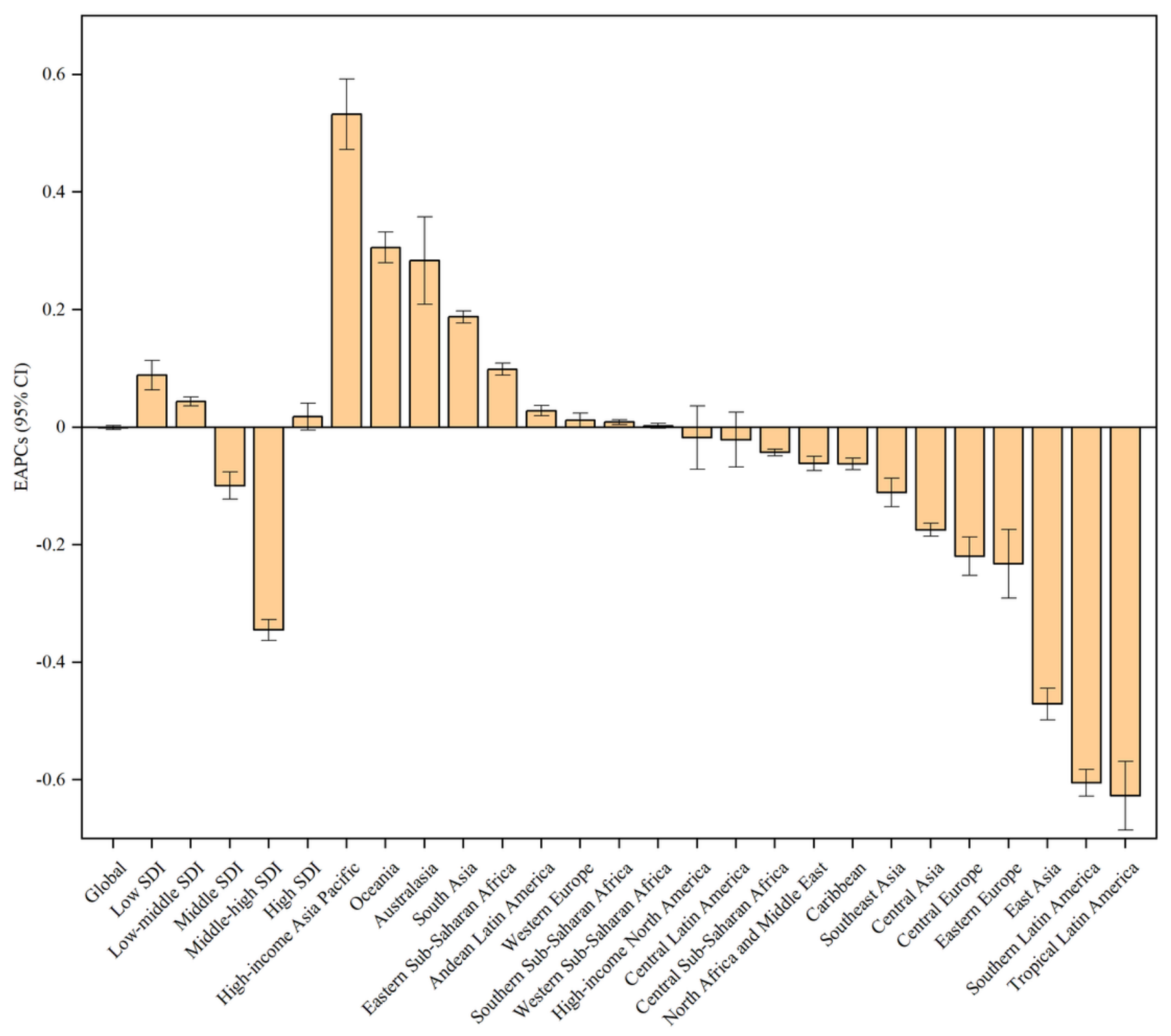

Figure 2

The EAPCs of hepatitis A ASRs from 1990 to 2017 at regional level. ASR, age-standardized incidence rate; EAPC, estimated annual percentage change; SDI: socio-demographic index. 

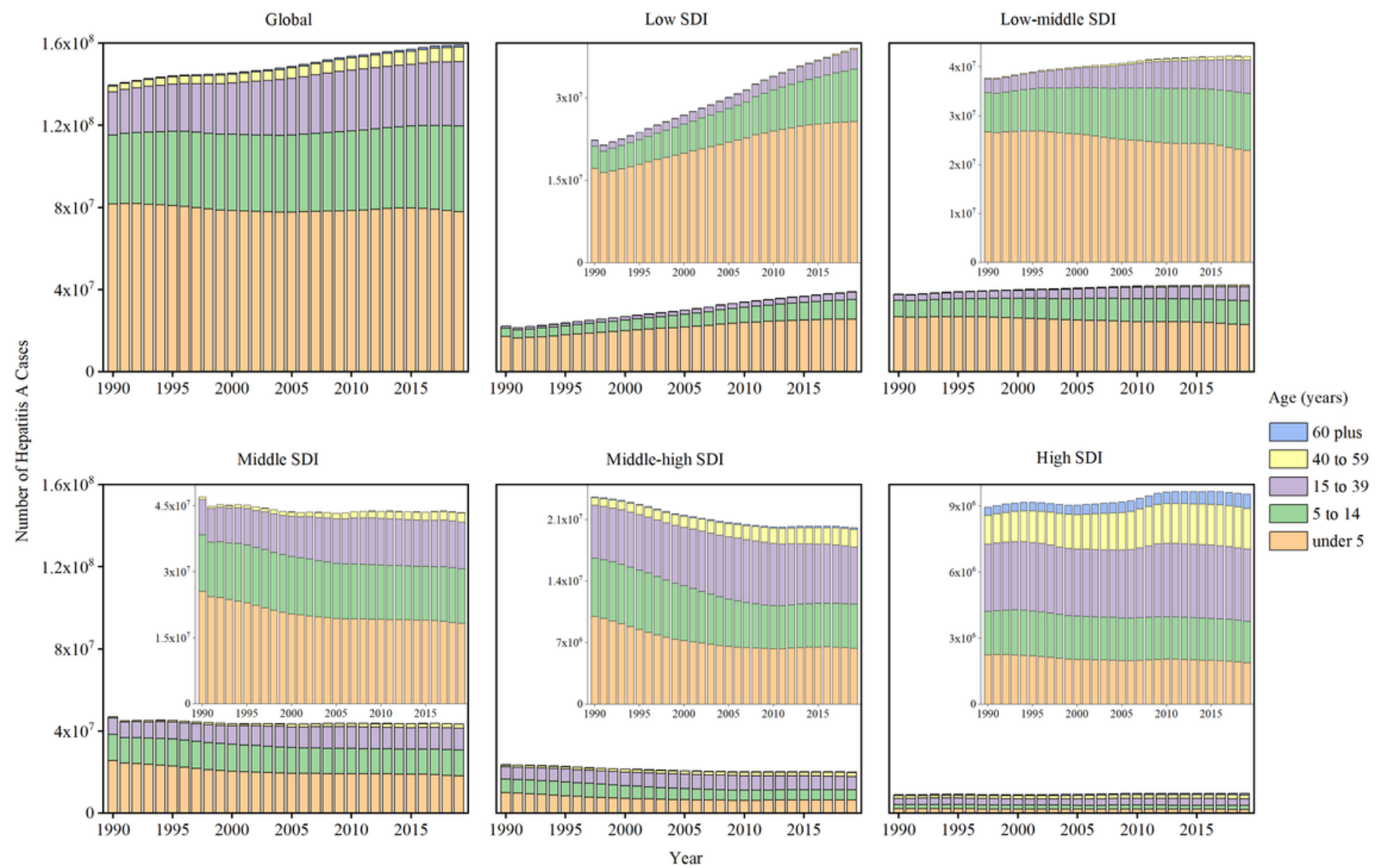

Figure 3

The number of incident cases of hepatitis A by age group, by SDI regions, from 1990 to 2019. The data of 5 SDI regions are presented in the top-right panel. SDI: socio-demographic index. 

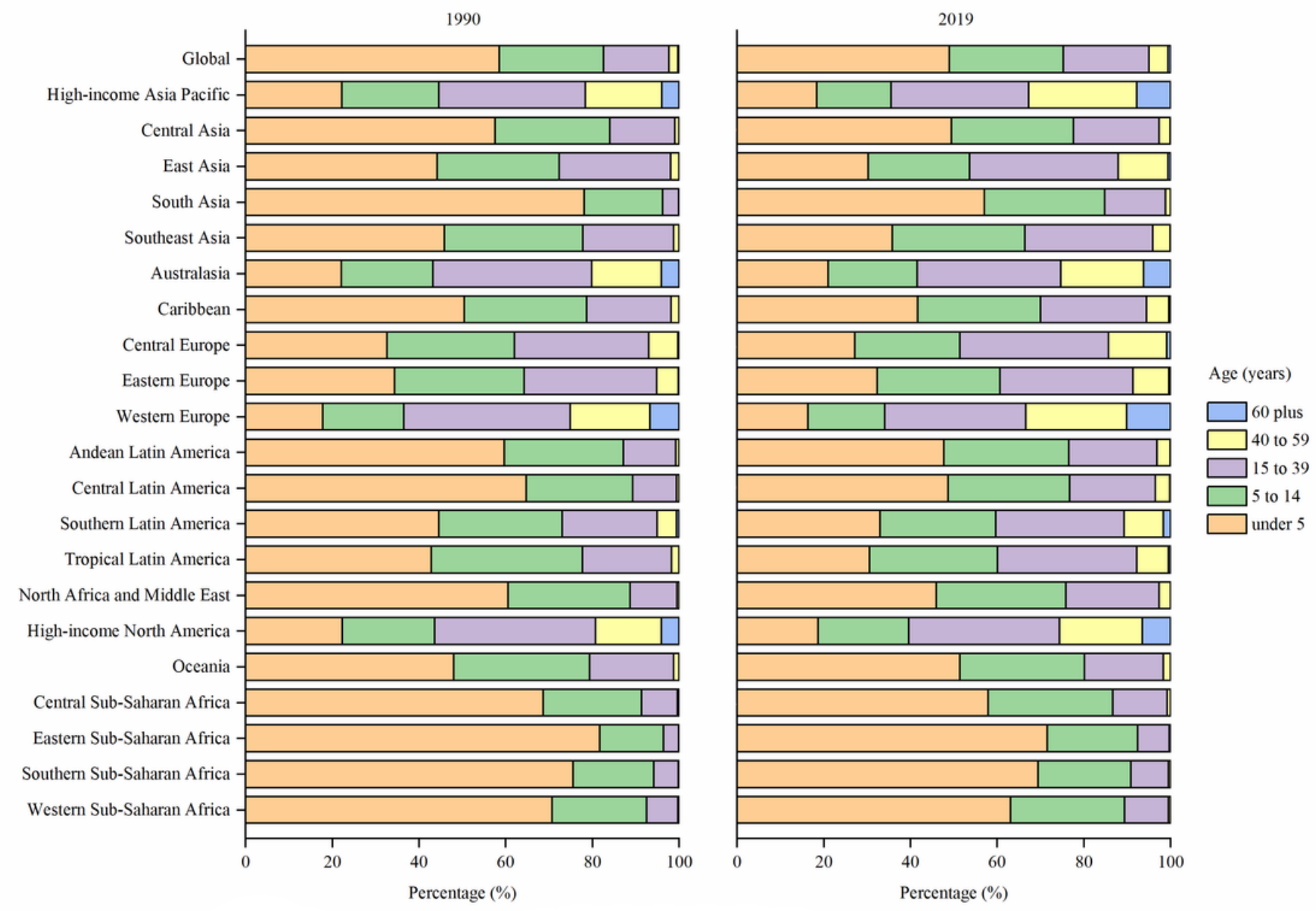

\section{Figure 4}

The age distribution of incident cases of hepatitis A by GBD region in 1990 and 2019. GBD: Global Burden of Disease. 

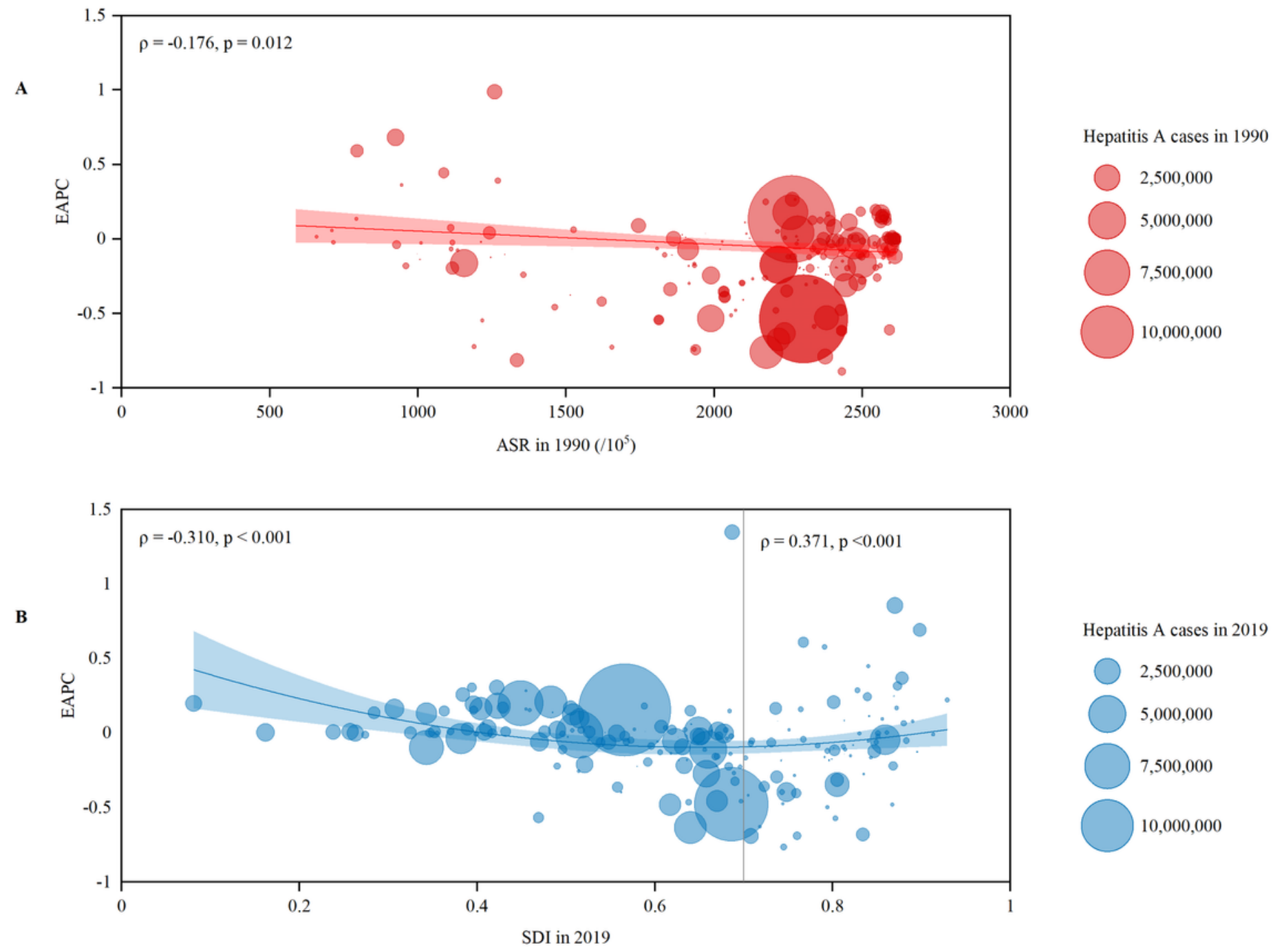

Hepatitis A cases in 2019

( $2,500,000$ $5,000,000$ $7,500,000$ $10,000,000$

\section{Figure 5}

The EAPCs of hepatitis A ASRs at countries and territorial level. (A) The correlation between EAPC and ASR of hepatitis A in 1990. (B) The correlation between EAPC and SDI in 2019. The incident cases of hepatitis A from 204 countries and territories were represented by the circles. The size of circles increased with the incident cases of hepatitis $A$. The $\rho$ indices and $p$ values were derived from Pearson correlation analysis. ASR, age-standardized incidence rate; EAPC, estimated annual percentage change; SDI: Sociodemographic index.

\section{Supplementary Files}

This is a list of supplementary files associated with this preprint. Click to download. 
- TableS1S2S3.docx

Page 23/23 